\title{
PERPETUAL PARADOXES: A NEW CRITICAL READING OF “THE LAKE ISLE OF INNISFREE” AND “STOPPING BY WOODS ON A SNOWY EVENING”
}

\author{
G. M. Javed Arif \\ English Discipline, Khulna University, Khulna-9208, Bangladesh \\ KUS: 21/18: 011021
}

Manuscript submitted: October 01, 2021

Accepted: December 11, 2021

\begin{abstract}
"The Lake Isle of Innisfree" by R. Frost and "Stopping by Woods on a Snowy Evening" by W. B. Yeats are two of the most representative poems of these poets. Part of their universal appeal lies in their messages and their craftsmanship, and both the qualities relate to the New Critical conception of poetry. Since New Criticism as a literary theory, originating in the early twentieth century, seeks to explore poems through some central points of references in a close reading, this present study takes paradoxes as a central point of reference for a close reading of the two poems and attempts to unveil their poetic enigma by examining what tensions the paradoxes create through the speakers' grappling with the dilemmas they are facing, how the paradoxes are being resolved or left unresolved, what similarities the two poems share in this regard, and what poetic unity the poems ultimately attain through the development of these paradoxes.
\end{abstract}

Keywords: Poetry, theory, new criticism, paradox, close reading, poetic unity

\section{Introduction}

W. B. Yeats's “The Lake Isle of Innisfree" and R. Frost's "Stopping by Woods on a Snowy Evening” are among the most representative poems of these two poets, and both contain universal appeal to the readers, which seems to emerge from the simplicity of form and message, for which they are often anthologized and included in introductory courses on poetry. This study seeks to investigate if the universal attraction of these two poems lies in their use of paradoxes, which in poems make the language complex and serve to attain a kind of artistic unity. In the present study, the theory of New Criticism will be used in a comparative reading of the two poems since this theory seeks to study the paradoxical language of a poem and how it contributes to the poetic unity.

\section{Theoretical Framework}

New Criticism has been called a "theory" (Leitch et al., 2018, p.3), an "important theoretical movement" (Culler, 2000, p. 121) as well as a "critical theoretical movement" and "a crucial starting-point for the development of critical theory in the second half of the twentieth century" (Matterson, 2006, p. 166). Unlike "traditional literary criticism", which typically "enacts its particular studies of the literary text" on the "grounding assumptions of humanism" (Rice \& Waugh, 1992, p. 2-3), theory continually asks questions about "authorship, criteria of value, contexts of reading, and the definition of 'literature" (Waugh, 2006, p. 2).

New Criticism, in its theoretical mode of reading practice, is "an explicit emptying out of literary interpretation in order to highlight intrinsic artistic craft and form while ruling out such extrinsic matters as 
morality, psychology, and politics" (Leitch et al., 2018, p.3). New Criticism, which maintains that "the design or intention of the author is neither available nor desirable as a standard for judging a work of literary art" (Wimsatt \& Beardsley, 1946), also discounts "affective criticism" (Wimsatt \& Beardsley, 1949). "During the mid-twentieth century, the New Criticism became the dominant critical practice in North American and British universities, and it remains influential today, especially in the introductory literature classroom" (Leitch et al., 2018, p.3). The New Critics focus on "ambiguity, paradox, irony, and the effects of connotation and poetic imagery", seeking to show "the contribution of each element of poetic form to a unified structure" (Culler, 2000, p.122). For them, “Meaning' is found neither in a simple paraphrase of the text, nor in propositions extracted from it, but in carefully orchestrated and unified textual elements (for example, images, tropes, tones, and symbols)" (Leitch et al., 2018, p. 3).

For a New Critic, C. Brooks argues, there has to be a "central point of reference" which can be used to focus on the structure of the individual poems (Brooks, 2001, p. 1368). Though there are such other points of reference like symbol and irony (Leitch et al., 2001, p. 17), paradox as a central point of reference is selected in the present study.

According to Brooks, "the language of poetry is the language of paradox" (Brooks, 1949, p. 3), and "paradoxes spring from the very nature of the poet's language" because the poet uses a lot of connotations besides denotations, alters his words slightly and perpetually to form new and abrupt combinations and works "by contradiction and qualification" (Brooks, 1949, p. 9). New Criticism proposed to view a poem as seeking and possessing an organic unity which is not so much a "logical unity" as a "poetic unity", and thus such unity is achieved not through a logical process but through a dramatic one (Brooks, 1949, p. 89). "The conclusion of the poem," Brooks argues, "is the working out of the various tensions - set up by whatever means - by propositions, metaphors, symbols" (Brooks, 1949, p. 189). Furthermore, Brooks maintains that paradoxes, besides ironies and symbols, contribute significantly to creating the "structure of poetry"; and, therefore, the poet's continual attempts at "blurring out distinctions, effecting compromises, or at the best, coming to his conclusions" are not to be considered meaningless and unnecessarily obstructive (Brooks, 1949, pp. 89, 190, 191).

In this study of paradoxes in the two poems, this New Critical reading method will be used, which has also been adopted in various degrees by other theories (Leitch et al., 2018, p. 901) and has become known as "close reading of a text" (Brooks, 2001, p. 1369) and also as "intrinsic (or formalist) criticism" (Leitch et al., 2001, 1351), because it considers all the above-mentioned techniques of poetic activity in its interpretative task.

\section{Discussion}

For each of these two poems, "The Lake Isle of Innisfree" and "Stopping by Woods on a Snowy Evening", some paradoxes are chosen as central points of reference, and for such an analysis of a poem close reading will be used. In "The Lake Isle" there is a paradox almost invisible, but still present and can be employed as a central point of reference to focus on the structure of the poem. When Yeats says, "And I shall have some peace there, for peace comes dropping slow, / Dropping from the veils of the morning to where the cricket sings", he is referring to some paradox central to the poem's structure and to the condition his speaker is experiencing. Two most important metaphors of the poem occur here in the middle of the poem not for anything casual, but for a certain poetic unity; thus the metaphorical veils of the morning cloaks the metaphorical dropping of peace.

The central paradox of "The Lake Isle" revolves around the idea of peace and more importantly around the paradoxical situation the poet finds himself in. Two instances of ratiocination occur in the poem and both at the beginning of the second and third stanzas as if such arguments would validate the poet's forsaking of the city for the sake not of nature, as might the Romantic legacy of poetry would dictate, but of peace as an already urban dweller absorbed fully in the urban engagements would covet, not because he finds solace in a Romantic appreciation of nature, but because he is beset with maladies of city life. The paradox of the poem lies exactly in this situation the poet portrays here. If he so desperately needs peace why does he seek 
Khulna University Studies Volume 18(2): 1-8: 2021

DOI: https://doi.org/10.53808/KUS.2021.18.02.2118-ah

"some" peace only, and if he still desires some peace so fervently, why does not he leave the city? The question is not only why he seeks peace in nature, but also why he does not obtain peace in "the deep heart's core" when such an imagination soothes his mind. But imagination in his mind is associated with nature, and it is nature that in the first place provides this peace. However, the logic in the second stanza evinces that peace that ensues from nature is ultimately "some" peace only, and the logic in the third stanza demonstrates that it is the city, as nature's antithesis, that has captured the mind in such a way that nature is pushed into the deep unconscious region of the mind. Thus it is always a question of "some" peace, and always an unconscious seeking of peace, and always a failure, and always a desire. However greyed and shadowed by the city, nature is cogently present in the poem from the beginning to the end, and whatever the urgency for peace, the desire is always for some peace. The central paradox of the poem thus relates to "some" peace, which shows the poet's attempt at defining peace and also points to his unsuccess in his quest for peace which creates a tension in the poem.

And why is it "some peace"? Peace is usually conceived as unitary, unbroken, worthy of being felt or experienced as something abstract but having an effect which is soothing, calming, and rewarding. Such a positive experience like peace cannot be simply conceived as fragmentary, interrupted or incomplete. Even then, as it is sometimes expressed, "some peace" is not unusual either. Though not an unusual expression, "some peace" refers to a momentary, periodic experience which points to some discontinuity from a regular routine, which, if interrupted, can occasion "some peace" only, not total undifferentiated peace. The speaker in "The Lake Isle" is also signaling to the hectic schedule of city life, hectic even in the standard of that period of industrialization, as compared to the almost receded Romantic Period with its idyllic representation of an idealized time. Though historical analysis is not favored by New Criticism, occasional historical references are not completely eschewed; for example, Brooks in his "The Language of Paradox", could not but intermittently refer to historical nuances of some poems, with "Christian sainthood", "modern man" or some historical personages referred to in the poems (Brooks, 1949, pp. 10, 18). Yeats somehow even in 1888, at the time of his writing the poem (Merritt, 1998), showed that an experience of undifferentiated complete peace was not possible in an industrialized city at that point of history. Even then living in nature evinces for him the possibility of providing "some peace", though not complete peace, and even for this partial achievement Yeats appears ready to leave the city, nay abandon it altogether - a departure emphasized through repetition of the intention first expressed in the first line of the poem and then repeated in the third and last stanza: "I will arise and go now". His intention of forsaking the city and its "grey" existence is also mentioned in his contriving to live in the isle of Innisfree, which is enumerated at the beginning of the poem:

I will arise and go now, and go to Innisfree,

And a small cabin build there, of clay and wattles made;

Nine bean-rows will I have there, a hive for the honey-bee,

And live alone in the bee-loud glade.

Yeats ensconces his idea of peace not only in leaving the city, and in living in nature, but, more importantly, in living alone - the three requirements which are hard to fulfill and thus he is only contemplating to "go", but cannot actually go. As he contemplates on two separations, first from the city and then from the other individuals, he conjectures that peace will never be complete; yet he suggests that peace is totally absent in the present dilemma he is facing; in other words, neither the city nor its people can provide him any peace at all. Just as the cabin is to be constructed as "small", his peace is conceived to be partial; so it is but a yearning for "some peace", though never a complete peace. That such is the destiny of the city people, who are not philosophic minded like Henry David Thoreau (1817-1862) to live in an Walden of their own in some remote place in nature to ponder the present plight of the world and the remedies thereof, but fated to continue like this, or to occasionally feel the necessity of peace and plan to get this peace, but not to execute the plan, is amply stated by Yeats throughout "The Lake Isle", especially in the concluding lines: 
I will arise and go now, for always night and day

I hear lake water lapping with low sounds by the shore;

While I stand on the roadway, or on the pavements grey,

I hear it in the deep heart's core.

It is always a "stand[ing] on the roadway", but never the initiation of a journey, and ultimately the speaker remains fastened to his imagination of the beautiful abode of peace, but is immobile on the metaphorical "grey" pavements of the city; he dissociates himself from the traffic on the road but is capable only to pause and ponder whether to take a new direction for an imaginative fulfillment, and is ultimately destined never to undertake that journey. Even this momentary pause and reflection, planning and contemplation, imagination and endeavor, cannot provide any peace, for which only leaving the city and its people and living alone in nature might prove to be the only prerequisites. Thus is repeated the idea of peace, the imagination of a beautiful abode, the imagination of getting peace there, and the contemplation of the journey. And yet that peace imagined is not the undifferentiated total peace, but "some peace", though still worthy to obtain but impossible to obtain, as the poet only ruminates upon fulfilling the requirements, but never consummates the task, as if in the contemplation is the accomplishment.

Peace on the isle the poet conceives to be possible only through a "slow" coming, a gradual process, impossible in the accelerated city life; and thus peace remains impossible to obtain. So the images related to nature, worthy of providing such peace, though partial, contain but beautiful figures of speech like the metaphoric "drop[ping]" and "veils", which have only imaginative potential and are available only in imagination. So the poet suggests that though complete peace will always be impossible whether one lives in the city or in nature, and though the city offers no scope of peace at all, peace lies in contemplation, and more than contemplation in imagination.

Furthermore, there are other paradoxes in "The Lake Isle" which relate to the central one. While there is the desire for loneliness, there is the desire for company, not for one, but for many, though they be but bees, honey-bees, suggesting perhaps a desire for some feminine association. And though the speaker will "arise", peace will "drop"; the fluctuating movements giving the poem another paradoxical edge. Furthermore, there is a combination of light and dark which is somewhat contradictory as well; there is the morning as contrasted to the evening - the midnight and the noon being the climax of these two. There is thus "a purple glow" contrasted with "a glimmer". Everything ultimately becomes veiled; starting from the morning "veils" it finally resolves, as well as dissolves, into the greyness of the pavements, of the city, and of the deep recesses of the human psyche, where the poet seeks to resolve all paradoxes.

On the other hand, though the speaker seeks "peace", which in the finals stanza combines the "deep heart's core" with "low sounds" of the "lake water", he has already spoken of seeking peace by living in "the bee-loud glade". Loudness and lowness of sounds seem contradictory, and thus paradoxical, when related to the seeking of peace; they are what the poet's mind thinks of: through "low sounds" in the depth of a meditative mind, while in an imaginative mind it is but a reverberating dale. Therefore, the idea of quiet peace becomes an idea of sonorous peace, part of the central paradox.

In an effort to resolve this paradox, the poet has already used the songs of the crickets in the second stanza, and quietened the sound of the singing linnets: "And evening full of the linnet's wings"; in other words, by imparting to the auditory image a visual nuance, and thus softening the idea of sonorous peace, but augmenting the idea of some peace, he seeks to make the sound suitable to a calming mind, which is ultimately made available in the final line of the final stanza, "in the deep heart's core", as if the unfathomable depth, at least an immense depth in the psyche, will absorb all sounds and noises and thereby provide the peace sought after from the very first line of the poem. However, just as the journey seems to have stopped the very moment it has started, and is forever being contemplated, or rather imagined, to resume, but is never in actuality resumed, peace lies forever in imagination, and in contemplation, forever sought and never obtained, as if in seeking is peace, in contemplating is roaming, and in imagining is beauty. "I will arise and go now" in the first and last stanzas of the poems dramatizes a moment of perpetual decision and perpetual resolve, only 
Khulna University Studies Volume 18(2): 1-8: 2021

DOI: https://doi.org/10.53808/KUS.2021.18.02.2118-ah

to be left perpetually unresolved, and thus gives the poem less a logical unity than a dramatic momentum. The paradoxes reach a height in the last line of the poem, but achieve no final resolution, and it is in its irresolution that the everlasting enchantment of the poem lies.

To speak of Frost's poem "Stopping by Woods on a Snowy Evening", the paradoxes present in the last stanza may be regarded as the central point of reference: "The woods are lovely, dark and deep". Undoubtedly, "dark and deep" is not oxymoronic to create a puzzle, it is a simple expression, lending a sense that it is too often used and thought to be so easily understood even though it has enough connotations associated with it; however, the pairing of "lovely" to this "dark and deep" creates quite a paradox. The normal question that baffles the mind, even though momentarily, is: How can something "dark and deep" be "lovely"? Or rather, how can something "lovely" be "dark and deep"? Which of these two paradoxes first perplexes the mind is another question, and how many paradoxes lie here points to a paradoxical omnipresence, and this baffles the reader when he or she reads the poem from the beginning to the end, again and again. The woods are first described as "lovely", which is apparently the only word in this poem associated with beauty, and then the more enigmatic expression, "dark and deep", occurs. One of the enigmas, or enigmatic beauties of the poem, is that until the readers reach in their journey the last part of the poem, they will not completely understand how mesmerizing the beauty is that compels the rider to stop his horse here, or how enigmatic the paradoxes make the poem so that the readers feel compelled to pause and wonder. Woods filling up with snow can generate many other meanings, for example for a hunter; and the readers do not know much about the identity of the rider till the mention of the "promises", which itself is so vague that the metaphor becomes quite universal to encompass all possible qualifications.

When the readers came across the rider stopping in the "darkest evening of the year", they began to associate the darkness with every possible negative connotation, ranging from the painful and distressing to the troublesome and burdensome, and beyond, but not with any positive one. And that very negative darkness is later associated with something beautiful to create an intensely and profoundly paradoxical enchantment "lovely, dark and deep". Part of the enigma the total structure of the poem creates is through this changing of association with the word "dark", first as negative and then as positive, though the word "dark" itself is usually considered as negative, sinister or even evil. Moreover, when the rider seems mesmerized with the falling of snow, it is normally assumed that it is the color white that captivates him, though the process of woods filling up with snow seems to be what ultimately captures the mind of the rider as beautiful.

However, the very juxtaposition of darkness and light, the white snow and the dark evening, just like the juxtaposition of morning and evening, noon and midnight in "The Lake Isle", may be described as what creates this indescribable beauty and the ineluctable enigma in Frost's poem. Thus, when the adjective "dark" comes to qualify beauty in the expression, "lovely, dark and deep", the reader is surprised, just like the rider has been awakened through his little horse's reaction in the previous stanza. Moreover, when it is "easy wind" and "downy flake" coming just in the previous line as something very light and easy-going, and thus so positive, any dark thing coming suddenly seems quite disturbing; yet the expression, "dark and deep", somehow minimizes that feeling of disturbance in its combination with the "lovely". Furthermore, when the lake is "frozen", the appearance of depth, though not the actual depth, of the lake comes as a contradiction; in fact, the lake is the only other object that is combined with the woods with a conjunction, as the rider stands "Between the woods and frozen lake" and watches them, the interest being on the woods. Perhaps the rider in his present dilemma dislocates the association of depth from the lake and attaches it to the woods, which is why the woods get this paradoxical expression. Yet the poem embodies more paradoxes related to the central one, creating multiple tensions in the poem: if the woods are dark, why the evening is the "darkest"? And if the woods are still "lovely", how can it be so in the "darkest evening"? What qualities are then to be attributed to this darkest evening and the dark woods? What symbolic significance? 
Whether the woods are a symbolic object of enigmatic beauty, shown through such paradoxes and elaborated throughout the poem, or whether the poem itself is an object of such a mysterious beauty, the central paradox of "lovely, dark and deep" goes a long way in creating various interpretations of the poem. The poet does not have to resolve the paradoxes, for he keeps his or the rider's "promises" undefined, unspecified. The metaphorical expression of "miles to go before I sleep" also contributes to such an unspecificity. What sleep, when and where, to expand their symbolic range? And most importantly, after doing what? Such symbolic, unspecific qualifications of "sleep" and "promises", the plural making it more unspecific, only compound the paradoxes; and yet it is this unspecificity that takes this poem to the hearts and minds of most of its readers, for whom this central paradox and this lack of particularity is a perpetual source of reflection upon their own situations. Frost achieves a universal effect through this central paradox and by developing it thus through metaphors and symbols throughout the poem. That symbolic unspecificity is even present from the beginning of the poem, as the owner of the woods is not only not mentioned but also left as someone not at all intimate.

Does Frost's poem then leave the paradoxes unresolved? The answer is both yes and no; such is the poem's power of paradoxes and its slow development that it includes both possibilities. Part of the poems' universal appeal rests in its irresolution, in its unspecificity, in its leaving the paradoxes unresolved, all of which contribute to the exquisite enigma of the poem, which defies logical unity but embraces a dramatic coherence. If Frost also seems to be offering a resolution of the central paradox through a proposition: "But I have promises to keep", which certainly contests the appealing nature of the object of beauty, not to belittle it but to overcome it, the struggle in the mind of the rider/speaker becomes so intense that another proposition is presented, which has to be repeated too: "And miles to go before I sleep". What promises and what distances and what sorts of sleep these are become yet further sources of unspecificity, and though they seem to contribute to the poet's attempt at resolving the paradoxes, they but go a long way to compounding the central paradox of the "lovely, dark and deep"; on the one hand, they seem to point to some sort of resolution, and on the other hand, they fail not to intensify the paradox.

Frost's paradox of enigmatic beauty, "lovely, dark and deep", is a more profound version than Yeats's paradox of the quest for peace, or "some peace"; yet both the poets on their journeys are engaging their speakers in the mode of a journey either to be started or to be continued, and as both the speakers pause to contemplate and enjoy, their journeys never reach an end. Both the poets keep the paradoxes open, resolved and yet not fully resolved. Yeats's speaker would embark on the journey for "some peace", but the journey ends "on the roadway, or on the pavements grey", while Frost's speaker stops in his journey, enjoys things he finds captivating, and thinks of restarting the journey, but can hardly do so. Both the poets keep their speakers momentarily paused, letting them ruminate on the paradoxes or problems they are seeing before them, and both the poets want the readers to share the paradoxes and try to resolve them on their own. Frost's "frozen lake" is not like Yeats's lake of Innisfree; it has its own depth and mystery, like the natural depth of Yeats's lake, where the "lake water [is] lapping with low sounds by the shore". Whereas it is primarily a lake that Yeats uses to create his paradox and solve it, although in the form of a lake isle, Frost mentions a lake but makes it frozen and instead chooses the woods to create his paradox. But in each case a paradox is central to the poem, and it is possible to focus on its poetic structure by taking the paradox as a central point of reference through a close reading of the poem.

In both the poems an attempt at resolving the central paradox is unmistakably present, as resolution is relegated to the realm of imagination, as if it is there where a resolution if at all possible can happen - in Yeats's poem everything occurs in the deep heart's core and in Frost's poem it is a beckoning to the realm of sleep. The conflict between reality and imagination reigns in both poems, and reality is presented as uncommonly powerful, almost as equal as imagination itself. In Yeats's poem imagination can be conceived as a fertile ground for both the origin and resolution of the paradox; however, in Frost's poem imagination seems less as a realm for the resolution of the paradox than its origin. 
Khulna University Studies Volume 18(2): 1-8: 2021

DOI: https://doi.org/10.53808/KUS.2021.18.02.2118-ah

Both "The Lake Isle of Innisfree" and "Stopping by Woods on a Snowy Evening" are exercises in a paradoxical journey - journey is started and also halted, on the "pavements grey" and between "the woods and frozen lake", but never again restarted, though a resumption is forever in mind. Peace is sought but not yet obtained, beauty is enjoyed and not yet forsaken. The paradoxes are thus resolved but partially, in a perpetual possibility of resolution, as if a final resolution is forever sought and forever delayed just as in a Keatsian wellwrought urn, which for C. Brooks, who uses occasional pertinent references to various literary texts in his New Critical readings of poems, is a symbol of a well-crafted poem (1949, p. 19). This seemingly deliberate powerful failure to resolve the paradoxes in these two poems is, paradoxically, the sure sign of the exquisitely artistic poetic craftsmanship.

To be or not to be, that is not the question, to rephrase Shakespeare in Hamlet, yet in a way that is the question. The decision is taken, but not yet implemented, and the moment of taking the decision through imagination and contemplation is eternalized in both the poems. Such is the fate of Yeats's and Frost's speakers, like Keats's "Bold Lover" in "Ode on a Grecian Urn", that "never, never canst thou kiss, / Though winning near the goal". "The Lake Isle" and "Stopping by Woods", like any poem or art object of enigmatic paradoxical beauty, for example Keats's Grecian urn, have embodied such a universal paradox of human mind showing an exquisite poetic unity that is achieved through metaphorical condensation and an expansive symbolic range. How to eternalize that moment of paradox in poetic imagination and poetic language is the dilemma that both Yeats and Frost, like their great predecessors, have encountered and embodied in these two poems, imparting to their readers a sense of wonder that the enthralling beauty that engulfs the mind in creating such a paradox can be poetry itself.

\section{Conclusion}

Both W. B. Yeats and R. Frost in their poems, "The Lake Isle of Innisfree" and "Stopping by Woods on a Snowy Evening", have used some paradoxes as central to the poems, which taken as a central point of reference evinces through a close reading the poets' artistic process of creating and resolving tensions in the poems. Both the poets choose to let the paradoxes remain in a perpetual mode of irresolution, though with a seemingly coveted desire for resolution.

All this paradoxical journey, emerging in imagination and contemplation of the speakers, points to the poets' desire to create an artistic whole. The poets have articulated the paradoxes with the use of metaphors and symbols in such a way that they develop towards the finality of the poems in a meticulously orchestrated way. The paradoxes in each poem lends to the poem a poetic unity which Brooks showed to be an artistic quality of a good poem - not a logical unity, but a dramatic verve. The resolution and irresolution of paradoxes run parallel with each other, blend, bifurcate, and continue as if in an eternal journey of seeking and finding beauty in a superbly crafted poem.

\section{References}

Brooks, C. (1949). The well wrought urn: Studies in the structure of poetry. Dennis Dobson Ltd.

Brooks, C. (2001). The formalist critics. In V. B. Leitch, W. E. Cain, L. A. Finke, Johnson, B. E., J. McGowan, \& J. J. Williams (Eds.), The Norton anthology of theory and criticism (1st ed., $\quad$ pp. 1366-1371). W. W. Norton \& Company.

Culler, J. (2000). Literary theory: A very short introduction. Oxford University Press.

Leitch, V. B., Cain, W. E., Finke, Johnson, B. E., McGowan, J., \& Williams, J. J. (Eds.). (2001). The Norton anthology of theory and criticism (1st. ed., pp. 1-28). W. W. Norton \& Company.

Leitch, V. B., Cain, W. E., Finke, L. A., McGowan, J., Sharpley-Whiting, T.D., \& Williams, J. J. (Eds.). (2018). The Norton anthology of theory and criticism (3rd ed., pp. 1-28). W. W. Norton \& Company. 
Arif G. M. (2021). Perpetual Paradoxes: A New Critical Reading of "The Lake Isle of Innisfree" and "Stopping by Woods on a Snowy Evening". Kbulna University Studies Volume 18(2): 1-8

Matterson, S. (2006). The New Criticism. In P. Waugh (Ed.), Literary theory and criticism: An Oxford guide (pp. 166-176). Oxford University Press.

Merritt, H. (1998). Rising and going: The 'nature' of Yeats's 'The lake isle of Innisfree'. English: Journal of the English Association, 47(188),103-109. htts://doi.org/10.1093/english/47.188.103

Rice, P., \& Waugh, P. (Eds.). (1992). Modern literary theory: A reader (2nd ed., pp. 1-4). Edward Arnold. Waugh, P. (Ed.). (2006). Literary theory and criticism: An Oxford guide (pp. 1-31). Oxford University Press.

Wimsatt, W. K., Jr., \& Beardsley, M. C. (1946, July-September). The intentional fallacy. The Sewanee Review, 54 (3), 468- 488. https://www.jstor.org/stable/27537676

Wimsatt, W. K., Jr., \& Beardsley, M. C. (1949, Winter). The Affective fallacy. The Sewanee Review, 57 (1), 31-55. https://www.jstor.org/stable/27537883 